\title{
Brachiaria physiological parameters in agroforestry systems
}

\section{Márcia Vitória Santos ${ }^{1}$ Evander Alves Ferreira ${ }^{1}$ Daniel Valadão $^{2}$ Fabiana Lopes Ramos de Oliveira $^{1}$ Vitor Diniz Machado ${ }^{3}$ Raul Ribeiro Silveira ${ }^{1}$ Matheus de Freitas Souza ${ }^{3^{*}}$}

\footnotetext{
${ }^{1}$ Universidade Federal dos Vales do Jequitinhonha e Mucuri (UFVJM), Diamantina, MG, Brasil.

${ }^{2}$ Universidade Federal Rural do Semi-Árido (UFRSA), Mossoró, RN, Brasil.

${ }^{3}$ Universidade Federal de Viçosa (UFV), Viçosa, MG, Brasil. E-mail: freitasouza@yahoo.com.br. "Corresponding author.
}

\begin{abstract}
This study aimed to assess the effects of Eucalyptus and maize shading on characteristics related to water use by Brachiaria in agroforestry systems. Treatments were arranged in a split-split-plot design, with plots consisting of different spacing between Eucalyptus plants $(12.0 \times 2.0 \mathrm{~m}$ and $12.0 \times 4.0 \mathrm{~m})$, split-plots of different distances between Brachiaria and Eucalyptus $(6.0,4.0$, and 2.0m), and split-split-plots of Brachiaria sowing sites (maize row and inter-row). One treatment with Brachiaria under full sunlight was included. Bread grass intercropping in maize inter-rows associated with the densest Eucalyptus spacing and bread grass proximity to Eucalyptus tree crowns adversely affected the stomatal conductance, internal carbon, and transpiration rate of bread grass. Water use efficiency of bread grass intercropped in maize rows decreased, regardless of the Eucalyptus plot design and distance between forages and trees.

Key words: Urochloa brizantha, production physiology, crop-livestock-forest integration.
\end{abstract}

Parâmetros fisiológicos da braquiária em diferentes arranjos do sistema agrossilvipastoril

RESUMO: O objetivo desta pesquisa foi avaliar os efeitos do sombreamento ocasionado por plantas de eucalipto e milho nas características relacionadas ao uso da água da braquiária em sistema agrossilvipastoril. O experimento foi realizado no delineamento em blocos casualizados, com quatro repetições. Os tratamentos foram arranjados em esquema de parcelas subsubdivididas, comas parcelas representadas constituídas pelos espaçamentos de plantio do eucalipto (12x2 e 12x4m), as sub-parcelas da distância da braquiaria e o eucalipto (6; 4 e $2 \mathrm{~m})$ e a subparcela do local de cultivo da braquiária (linha e entrelinha do milho). Além disso, foi adicionado um tratamento composto pela braquiária cultivada a pleno sol. O cultivo do capim-maradu na entrelinha do milho associado ao sombreamento intenso proporcionado pelo espaçamento mais adensado de eucalipto $(12 \times 2 m)$ e a proximidade das plantas de capim-marandu às copas das árvores de eucalipto altera negativamente a condutância estomática, o carbo interno e a taxa transpiratória das plantas de capim-marandu. A eficiência no uso da água das plantas de capim - maradu é reduzida independente do arranjo espacial do eucalipto e da distância entre aforrageira e as árvores quando a forrageira é cultivada na linha do milho.

Palavras-chave: Uroclhoa brizantha, fisiologia da produção, integração lavoura-pecuária-floresta.

\section{INTRODUCTION}

Forage plants of the genus Brachiaria (Syn. Urochloa) are commonly used in croplivestock-forest integration (CLFI) systems because of their resistance to competition with agricultural crops and their good adaptation to understory of trees (PACIULLO et al., 2007). Species grown in the understory, including Brachiaria, are exposed to limited light caused by shading from agricultural and/or forestry components. However, this effect may vary with the spacing and population density of agricultural and forestry components and the growth phase of plant species (MADDONNI et al., 2001).

Shading level provided by Eucalyptus may adversely affect the physiological characteristics of bread grass depending on the spacing adopted and the proximity between maize plant rows in intercropping systems. Assessment of those parameters enables a better understanding of the growth and development of intercropped plants, which are used as indicators to assist the management and success of agroforestry systems. Thus, this study aimed to assess the effects of Eucalyptus spacing and bread grass plant position in relation to maize (row and inter-row) on water 
use-related characteristics of forage plants grown in agroforestry systems.

\section{MATERIALS AND METHODS}

Assessments were performed in 2014, in a 5-year-old agroforestry system area with the Eucalyptus clone 3336 (Eucalyptus grandis $\times$ E. urophylla) and forage of the genus Brachiaria (Syn. Urochloa) grown in a north-south direction. Soil in the experimental area is classified as Red-Yellow Latosol of clayey texture and soft-wavy terrain, with the following chemical characteristics: $\mathrm{pH}$ in $\mathrm{H}_{2} \mathrm{O}: 5.60 ; \mathrm{P}: 13.1 \mathrm{mg} \mathrm{dm} \mathrm{dm}^{-3}$ (Mehlich); K: 41.00mg dm${ }^{-3} ; \mathrm{Ca}^{2+}: 3.33 ; \mathrm{Mg}^{2+}$ : 0.57; $\mathrm{Al}^{3+}$ : $0.03 \mathrm{cmolc} \mathrm{dm}^{-3}\left(1 \mathrm{~mol} \mathrm{~L}^{-1} \mathrm{KCl}\right)$; cation-exchange capacity (CEC; total $[\mathrm{T}]): 5.99 \mathrm{cmolc}^{-3}$; base sum: 2.34cmolc dm-3 $\mathrm{H}+\mathrm{Al}: 3.65 \mathrm{cmolc} \mathrm{dm}{ }^{-3} ; 2.37 \mathrm{dag}_{\mathrm{kg}^{-1}}$ organic matter; and $20.35 \mathrm{mg} \mathrm{dm}^{-3}$ P-rem.

The experimental design used consisted of completely randomized blocks, with four replicates. Treatments consisted of Brachiaria brizantha, cv. 'Marandu' (Syn. Urochloa brizantha, cv. 'Marandu'; bread grass) intercropping with maize and Eucalyptus in agroforestry systems, arranged in a split-split-plot design, with plots consisting of different Eucalyptus sowing spacing $(12.0 \times 2.0 \mathrm{~m}$ and $12.0 \times 4.0 \mathrm{~m})$, splitplots consisting of different distances between Brachiaria and Eucalyptus (6.0, 4.0, and 2.0m), and split-split-plots consisting of Brachiaria sowing sites (maize row and inter-row). Furthermore, a control consisting of Brachiaria grown under full sunlight was included. The maize used was a double-BM207 hybrid with flat leaves.

The experimental plots were $12-\mathrm{m}$ wide by $12-\mathrm{m}$ long, totaling an area of $144 \mathrm{~m}^{2}$, consisting of two Eucalyptus rows, interspersed with bread grass and maize, in intercropped plots. The mono-cropping plots were $12 \mathrm{~m}$ wide and $10 \mathrm{~m}$ long, totaling an area of $120 \mathrm{~m}^{2}$.

Maize hybrids and forage were sown in November 2014 in a no-till crop-production system. Six hybrid seeds were sown per linear meter, using $1.0-\mathrm{m}$ inter-row spacing, using only the central $8 \mathrm{~m}$ between the tree rows, in intercropped plots. Forage species was sown in rows and inter-rows of the maize crop, at a 2-cm depth, using multiple sowing (Semeato SHM 11/13). Forage was sown in maize inter-rows $(1.0 \mathrm{~m})$ in a single row. B. brizantha $\mathrm{cv}$. 'Marandu' viable, pure seeds ( $4 \mathrm{~kg}$ $\left.\mathrm{ha}^{-1}\right)$ were used in all treatments. Sowing fertilization of $400 \mathrm{~kg} \mathrm{ha}{ }^{-1} 8-28-16\left(\mathrm{~N}-\mathrm{P}_{2} \mathrm{O}_{5}-\mathrm{K}_{2} \mathrm{O}\right)$ formulation was used. Nitrogen top-dressing was performed 30 days after maize emergence at a dose of $100 \mathrm{~kg} \mathrm{ha}^{-1} \mathrm{~N}$.

Mean shading was estimated by the percentage ratio between irradiance $\left(\mathrm{Wm}^{-2}\right)$ measured in the maize canopy $(3 \mathrm{~m})$ and in the forage canopy $(1 \mathrm{~m})$, measured under full sunlight $(1 \mathrm{~m})$ at 110 days after sowing (Table 1$)$. The LI-COR plant canopy analyzer, model LAI 20001, was used (WELLES \& NORMAN, 1991).

Brachiaria physiological parameters were assessed using an infrared gas analyzer (IRGA), brand ADC, model LCA 4 (Analytical Development Co. Ltd, Hoddesdon, UK). Assessments were made once between 08:00 and 10:00h to ensure homogeneous environmental conditions. During the assessment period, the maize plants were at phenological stage $\mathrm{R} 3$, according to the scale proposed by RITCHIE et al. (1993). The following parameters were assessed: stomatal conductance of water vapors $\left(\mathrm{Gs}-\mathrm{mol} \mathrm{m}^{-1} \mathrm{~s}^{-1}\right)$, internal carbon concentration $\left(\mathrm{Ci}-\mu \mathrm{mol} \mathrm{mol}^{-1}\right)$, vapor pressure in the substomatal chamber, and transpiration rate $\left(\mathrm{E}-\mathrm{mol} \mathrm{H}_{2} \mathrm{O} \mathrm{m}^{-2} \mathrm{~s}^{-1}\right)$, also calculating the water use efficiency (WUE - mol $\mathrm{CO}_{2} \mathrm{~mol} \mathrm{H}_{2} \mathrm{O}^{-1}$ ). The WUE value was assessed by the ratio between the quantity of $\mathrm{CO}_{2}$ fixed by photosynthesis (photosynthetic rate) and transpiration $\left(\mathrm{WUE}=\mathrm{qCO}_{2(\mathrm{fixed})} / \mathrm{E}\right)$.

The middle third of the first fully expanded leaf, with a visible ligule, was measured (from top to bottom) in each experimental plot. Those assessments were performed in 12 bread grass plants per plot, with four plants per distance in Eucalyptus rows (2.0, 4.0, and $6.0 \mathrm{~m}$ ): two in maize rows and two in inter-rows, in intercropped plots. Six bread grass plants were randomly assessed in the mono-cropped plots as described for the intercropped plots.

Data were subjected to analysis of variance using the $\mathrm{F}$ test at a 5\% probability level, and Tukey's test was performed at $5 \%$ probability to assess the

Table 1 - Number of trees per arrangement $(\mathrm{N})$, height of Eucalyptus $(\mathrm{H})$, diameter of chest height (DAP), volume per tree (V), shading between rows $\left(\mathrm{S}_{\mathrm{E}}\right)$ and row $\left(\mathrm{S}_{\mathrm{L}}\right)$ and bread grass 110 days after sowing, in the corn canopy and in the forage canopy in agroforestry systems.

\begin{tabular}{lcccccccc}
\hline Spacing & $\mathrm{N}$ & $\mathrm{H}(\mathrm{m})$ & $\mathrm{DAP}(\mathrm{cm})$ & $\mathrm{V}\left(\mathrm{m}^{3}\right)$ & $\mathrm{S}_{\mathrm{E}}(\%)$ & $\mathrm{S}(\%)$ & $\mathrm{Hm}$ & $\mathrm{Hc}$ \\
\hline $12 \times 2$ & 416 & 35.22 & 23.24 & 0.435 & 30.4 & 58.2 & 2.79 & 83.2 \\
$12 \times 4$ & 208 & 29.26 & 27.34 & 0.622 & 41.3 & 68.3 & 2.91 & 85.1 \\
\hline
\end{tabular}


distance effect of bread grass intercropped in maize rows and inter-rows of Eucalyptus rows. The F test at 5\% was used to assess the effect of Eucalyptus spacing on forage photosynthetic characteristics. The SISVAR ${ }^{\circledR}$ software, version 5.6, was used for data analyses.

\section{RESULTS AND DISCUSSION}

\section{Bread grass intercropped in maize inter-rows}

Bread grass grown under full sunlight exhibited higher stomatal conductance (Gs) than forage plants in the intercropped system, in maize inter-rows, and spaced $2 \mathrm{~m}$ from the Eucalyptus rows, regardless of Eucalyptus spacing (Table 2). Spacing of tree species had no effect on the forage Gs.
Gs is proportional to stomatal number and size, stomatal opening diameter, and the vapor pressure gradient between the leaf mesophyll and the atmosphere. The control of stomatal opening and closing depends on a number of factors, including the vapor pressure deficit (VPD) between the atmosphere and the leaf intracellular spaces (CONCENCO et al., 2007). The tree component may reduce the light incidence due to increased shading, thus creating a microclimate with increased relative humidity in the understory. This reduces the VPD, favoring stomatal opening, and increasing the Gs. Conversely, the decrease in VPD between the atmosphere and the internal leaf space, resulting from the increased relative humidity, curtails the loss of water vapor from the leaf

Table 2 - Stomatal conductance $\left(G s-\mathrm{mol} \mathrm{m}^{-1} \mathrm{~s}^{-1}\right)$, internal carbon $\left(C i-\mu \mathrm{mol} \mathrm{mol}^{-1}\right)$, transpiratory rate $\left(E-\mathrm{mol} \mathrm{H}_{2} \mathrm{O} \mathrm{m}^{2} \mathrm{~s}^{-1}\right)$ and water use efficiency ( $W U E-\mathrm{mol} \mathrm{CO}_{2} \mathrm{~mol} \mathrm{H}_{2} \mathrm{O}^{-1}$ ) of bread grass plants grown in monoculture (full sunlight), and in intercrop with maize and eucalyptus at $12 \times 2$ and $12 \times 4$ m spacing's, sown between rows of maize, with distances of $6 ; 4$ and $2 \mathrm{~m}$ of eucalyptus plants.

\begin{tabular}{|c|c|c|c|}
\hline \multicolumn{2}{|c|}{ 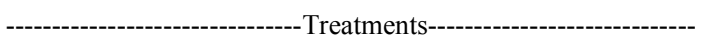 } & Spacing $12 \times 2$ & Spacing $12 \times 4$ \\
\hline & & \multicolumn{2}{|c|}{------------------Stomatal conductance (Gs - $\left.\mathrm{mol} \mathrm{m}^{-1} \mathrm{~s}^{-1}\right)-------------$} \\
\hline Bread grass in monoculture & Full sunlight & $0.29 \mathrm{a}$ & \\
\hline \multirow{3}{*}{ Bread grass in intercrop } & $6.00 \mathrm{~m}$ & $0.16 \mathrm{Aab}$ & $0.20 \mathrm{Aa}$ \\
\hline & $4.00 \mathrm{~m}$ & $0.14 \mathrm{Aab}$ & $0.14 \mathrm{Aab}$ \\
\hline & $2.00 \mathrm{~m}$ & $0.08 \mathrm{Ab}$ & $0.11 \mathrm{Ab}$ \\
\hline \multicolumn{2}{|c|}{$\mathrm{CV}(\%)$} & \multicolumn{2}{|c|}{28.79} \\
\hline & & \multicolumn{2}{|c|}{ 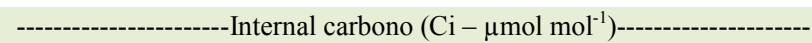 } \\
\hline & & Spacing $12 \times 2$ & Spacing $12 \times 4$ \\
\hline Bread grass in monoculture & Full sunlight & $164.95 \mathrm{a}$ & \\
\hline \multirow{3}{*}{ Bread grass in intercrop } & $6.00 \mathrm{~m}$ & $162.79 \mathrm{Aa}$ & $213.75 \mathrm{Aa}$ \\
\hline & $4.00 \mathrm{~m}$ & $183.46 \mathrm{Aa}$ & $185.47 \mathrm{Aa}$ \\
\hline & $2.00 \mathrm{~m}$ & $151.38 \mathrm{Ab}$ & $163.10 \mathrm{Aa}$ \\
\hline \multicolumn{2}{|c|}{$\mathrm{CV}(\%)$} & \multicolumn{2}{|c|}{18.25} \\
\hline & & \multicolumn{2}{|c|}{--------------------Transpiratory rate $\left(\mathrm{E}-\mathrm{mol} \mathrm{H}_{2} \mathrm{O} \mathrm{m}{ }^{2} \mathrm{~s}^{-1}\right)$---------------- } \\
\hline & & Spacing $12 \times 2$ & Spacing $12 \times 4$ \\
\hline Bread grass in monoculture & Full sunlight & $5.30 \mathrm{a}$ & \\
\hline \multirow{3}{*}{ Bread grass in intercrop } & $6.00 \mathrm{~m}$ & $3.35 \mathrm{Ab}$ & $3.07 \mathrm{Ab}$ \\
\hline & $4.00 \mathrm{~m}$ & $2.46 \mathrm{Ab}$ & $2.70 \mathrm{Ab}$ \\
\hline & $2.00 \mathrm{~m}$ & $1.50 \mathrm{Bb}$ & $2.31 \mathrm{Ab}$ \\
\hline \multicolumn{2}{|c|}{$\mathrm{CV}(\%)$} & \multicolumn{2}{|c|}{25.04} \\
\hline & & \multicolumn{2}{|c|}{------------Water use efficiency $\left(\mathrm{WUE}-\mathrm{mol} \mathrm{CO}_{2} \mathrm{~mol} \mathrm{H}_{2} \mathrm{O}^{-1}\right.$ )--------- } \\
\hline & & Spacing $12 \times 2$ & Spacing $12 \times 4$ \\
\hline Bread grass in monoculture & Full sunlight & $5.83 \mathrm{a}$ & \\
\hline \multirow{3}{*}{ Bread grass in intercrop } & $6.00 \mathrm{~m}$ & $5.56 \mathrm{Aa}$ & $6.29 \mathrm{Aa}$ \\
\hline & $4.00 \mathrm{~m}$ & $3.95 \mathrm{Ab}$ & $5.10 \mathrm{Aa}$ \\
\hline & $2.00 \mathrm{~m}$ & $3.15 \mathrm{Bb}$ & $5.37 \mathrm{Aa}$ \\
\hline \multicolumn{2}{|c|}{$\mathrm{CV}(\%)$} & \multicolumn{2}{|c|}{22.91} \\
\hline
\end{tabular}

${ }^{*}$ Means followed by a capital letter on the line do not differ from each other by the F-Test at 5\% probability and averages followed by a small letter in the column do not differ by the Tukey test with a $5 \%$ probability. 
to the atmosphere, explaining the lower Gs values reported in treatments spaced $2.0 \mathrm{~m}$ from Eucalyptus trees (OCHELTREE et al., 2014). Climatic conditions of cropping under full sunlight may increase the VPD, thereby increasing water loss through the plant stomata. Thus, even under conditions where stomatal closing is favored, the force resulting from the increased vapor pressure gradient between the leaf internal space and the environment increases the Gs.

In the $12.0 \times 2.0-\mathrm{m}$ spacing, Brachiaria plants exhibited internal carbon $(\mathrm{Ci})$ values lower than those subjected to the other treatments when located $2 \mathrm{~m}$ from the Eucalyptus rows and in maize inter-rows (Table 2). Transpiration and $\mathrm{CO}_{2}$ capture processes occur simultaneously and vary with stomatal opening. Plants tend to close their stomata when light levels are lower than the photosynthetically active radiation levels (COCHARD et al., 2002). Thus, the quantity of light available to the forage may compromise the levels of photosynthesis, reducing stomatal opening in the high-density treatments and when spaced $2.0 \mathrm{~m}$ from tree crops. This reduced stomatal conductance, reducing the leaf $\mathrm{Ci}$ values.

Bread grass plants grown under full sunlight have a higher transpiration rate (E) than those grown in the shade (Table 2), given the higher Gs reported in treatments under full sunlight. High Gs values suggested that plants have an increased capacity to loose water to the atmosphere, that is, increased stomatal transpiration. High-density spacing $(12.0 \times 2.0 \mathrm{~m})$ led to a lower transpiration rate in Brachiaria plants located $2 \mathrm{~m}$ from the Eucalyptus rows compared with low-density spacing $(12.0 \times 4.0 \mathrm{~m})$. The decrease in transpiration is associated with stomatal closing, according to BRODRIBB \& HILL (2000). As previously reported, light intensity may affect stomatal opening. However, the different conditions of high-density environments, including lower temperature and higher relative air humidity, curtailed water loss through the forage stomata.

Analysis of water use efficiency (WUE) by bread grass plants spaced 2.0 and $4.0 \mathrm{~m}$ from the Eucalyptus rows in the $12.0 \times 2.0 \mathrm{~m}$ plot design revealed lower values of forage water use efficiency than in plants grown under full sunlight and at a 6-m distance from Eucalyptus trees (Table 2).

Water use efficiency measures the number of $\mathrm{CO}_{2}$ moles fixed per mole of water lost. Thus, this variable is directly related to stomatal opening time because water is lost by transpiration during plant $\mathrm{CO}_{2}$ assimilation for photosynthesis at a variable intensity, depending on the potential gradient between the leaf and the atmosphere (CONCENCO et al., 2007). However, the plant must fix atmospheric $\mathrm{CO}_{2}$ absorbed in its dry matter. Therefore, factors affecting photosynthesis may also affect the water use efficiency of plants.

The decreased light intensity imposed by the high-density plot design and increased proximity of forage plants to Eucalyptus trees may limit the plant photosynthetic rate $\left(\mathrm{CO}_{2}\right.$ fixed/ total irradiance), particularly for $\mathrm{C} 4$ plants. The $\mathrm{C} 4$ species have a light saturation point ranging from 1200 to $1600 \mu \mathrm{mol} \mathrm{m} \mathrm{m}^{-2} \mathrm{~s}^{-1}$, whereas that value peaks at approximately $800 \mu \mathrm{mol} \mathrm{m} \mathrm{m}^{-2} \mathrm{~s}^{-1}$ in $\mathrm{C} 3$ plants. Thus, a greater percentage drop in the quantity of $\mathrm{CO}_{2}$ fixed in $\mathrm{C} 4$ plants is observed when comparing the behavior of $\mathrm{C} 3$ and $\mathrm{C} 4$ plants in environments such as understories (KUBÁSEK et al., 2013).

Therefore, even in treatments in which higher $\mathrm{E}$ values were reported, including cropping under full sunlight, light limitation induced by the increased forage density and proximity to Eucalyptus trees may have compromised the atmospheric $\mathrm{CO}_{2}$ fixation, resulting in the low water use efficiency of plants located 2.0 and $4.0 \mathrm{~m}$ from the Eucalyptus trees in the $12.0 \times 2.0 \mathrm{~m}$ plot design.

\section{Bread grass sown in the maize crop row}

The water vapor stomatal conductance (Gs) of bread grass grown in maize rows decreased when the forage was grown in an intercropped system, regardless of the distance from Eucalyptus trees (Table 3).

Comparison of forage Gs values between cropping under full sunlight, in inter-rows, and in maize rows, clearly showedthat light plays a key role in controlling stomatal opening. Decreased temperature and increased relative air humidity are expected under conditions of decreased light intensity. This contributed to reduce the water loss by transpiration, thus favoring stomatal opening. However, the increased rates of shading resulting from forage intercropping in maize rows (58.2 and $68.3 \%$ ) may trigger changes in light quantity and quality reaching the leaves, thereby inducing plant stomatal closing (SHARKEY \& RASCHKE, 1981). This caused a greater reduction in Gs values than was observed in plants grown in inter-rows.

Brachiaria plants grown in maize rows $2.0 \mathrm{~m}$ from Eucalyptus rows exhibited lower internal carbon $(\mathrm{Ci})$ values than plants located at other distances when spaced $12.0 \times 2.0 \mathrm{~m}$ from the tree species, whereas no difference in this variable was assessed between treatments at $12.0 \times 4.0 \mathrm{~m}$ spacing. Comparison of spacing for distances between forage and Eucalyptus plants with forage plants under full sunlight showed that plants grown in rows $2.0 \mathrm{~m}$ from Eucalyptus trees 
Table 3 - Stomatal conductance $\left(\mathrm{Gs}-\mathrm{mol} \mathrm{m}^{-1} \mathrm{~s}^{-1}\right)$, internal carbon $\left(\mathrm{Ci}-\mu \mathrm{mol} \mathrm{mol}{ }^{-1}\right)$, transpiratory rate $(\mathrm{E}-\mathrm{mol} \mathrm{H} 2 \mathrm{O} \mathrm{m} 2 \mathrm{~s}-1)$ and water use efficiency -1) of bread grass plants grown in monoculture (full sunlight), and in intercrop with maize and eucalyptus at 12x2 and $12 \times 4 \mathrm{~m}$ spacings, sown in the maize row, with distances of $6 ; 4$ and $2 \mathrm{~m}$ of eucalyptus plants.

\begin{tabular}{|c|c|c|c|}
\hline \multicolumn{2}{|c|}{------------------------------Treatments------------------------------ } & Spacing $12 \times 2$ & Spacing $12 \times 4$ \\
\hline & & \multicolumn{2}{|c|}{--Stomatal condutance $\left(\mathrm{Gs}-\mathrm{mol} \mathrm{m}^{-1} \mathrm{~s}^{-1}\right)$} \\
\hline Bread grass in monoculture & Full sunlight & $0.29 \mathrm{a}$ & \\
\hline \multirow{3}{*}{ Bread grass in intercrop } & $6.00 \mathrm{~m}$ & $0.035 \mathrm{Ab}$ & $0.065 \mathrm{Ab}$ \\
\hline & $4.00 \mathrm{~m}$ & $0.060 \mathrm{Ab}$ & $0.080 \mathrm{Ab}$ \\
\hline & $2.00 \mathrm{~m}$ & $0.035 \mathrm{Ab}$ & $0.070 \mathrm{Ab}$ \\
\hline \multicolumn{2}{|c|}{ CV (\%) } & \multicolumn{2}{|c|}{57.24} \\
\hline & & \multicolumn{2}{|c|}{ 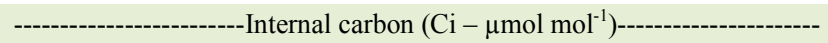 } \\
\hline & & Spacing $12 \times 2$ & Spacing $12 \times 4$ \\
\hline Bread grass in monoculture & Full sunlight & $164.95 \mathrm{a}$ & \\
\hline \multirow{3}{*}{ Bread grass in intercrop } & $6.00 \mathrm{~m}$ & $170.70 \mathrm{Aa}$ & $177.41 \mathrm{Aa}$ \\
\hline & $4.00 \mathrm{~m}$ & $123.82 \mathrm{Aa}$ & $163.75 \mathrm{Aa}$ \\
\hline & $2.00 \mathrm{~m}$ & $77.52 \mathrm{Bb}$ & $164.55 \mathrm{Aa}$ \\
\hline \multicolumn{2}{|c|}{ CV $(\%)$} & \multicolumn{2}{|c|}{25.63} \\
\hline & & \multicolumn{2}{|c|}{ 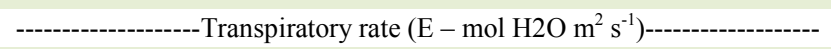 } \\
\hline & & Spacing $12 \times 2$ & Spacing $12 \times 4$ \\
\hline Bread grass in monoculture & Full sunlight & $5.30 \mathrm{a}$ & \\
\hline \multirow{3}{*}{ Bread grass in intercrop } & $6.00 \mathrm{~m}$ & $3.22 \mathrm{Ab}$ & $3.29 \mathrm{Ab}$ \\
\hline & $4.00 \mathrm{~m}$ & $1.15 \mathrm{Bb}$ & $3.20 \mathrm{Ab}$ \\
\hline & $2.00 \mathrm{~m}$ & $1.89 \mathrm{Bb}$ & $3.16 \mathrm{Ab}$ \\
\hline \multicolumn{2}{|c|}{ CV (\%) } & \multicolumn{2}{|c|}{25.09} \\
\hline & & \multicolumn{2}{|c|}{----------Water use efficience (WUE - $\mathrm{mol} \mathrm{CO}_{2} \mathrm{~mol} \mathrm{H}_{2} \mathrm{O}^{-1}$ )-------- } \\
\hline & & Spacing $12 \times 2$ & Spacing $12 \times 4$ \\
\hline Bread grass in monoculture & Full sunlight & $5.83 \mathrm{a}$ & \\
\hline \multirow{3}{*}{ Bread grass in intercrop } & $6.00 \mathrm{~m}$ & $3.33 \mathrm{Ab}$ & $4.18 \mathrm{Ab}$ \\
\hline & $4.00 \mathrm{~m}$ & $3.82 \mathrm{Ab}$ & $4.35 \mathrm{Ab}$ \\
\hline & $2.00 \mathrm{~m}$ & $2.03 \mathrm{Ab}$ & $3.78 \mathrm{Ab}$ \\
\hline \multicolumn{2}{|c|}{ CV (\%) } & \multicolumn{2}{|c|}{48.45} \\
\hline
\end{tabular}

"Means followed by a capital letter on the line do not differ from each other by the F-Test at $5 \%$ probability and averages followed by a small letter in the column do not differ by the Tukey test with a $5 \%$ probability.

had lower $\mathrm{C}$ i values in the $12.0 \times 2.0 \mathrm{~m}$ spacing (Table 3 ). The decreased Gs value in the high-density treatment $2.0 \mathrm{~m}$ from the Eucalyptus trees reflects the decreased forage stomatal opening, thus reducing atmospheric $\mathrm{CO}_{2}$ entry into the leaf mesophyll. Stomatal opening is little dependent on the internal carbon concentration in the substomatal chamber. However, increased forage shading affects stomatal opening, with a direct effect on the gas balance between the leaf internal area and the external medium (LORETO \& BONGI, 1989). Those results showed that conditions of low light intensity may decrease the internal carbon concentration of bread grass.

Brachiaria plants grown under full sunlight exhibited a higher transpiration rate $(\mathrm{E})$ than plants grown in plots where intercropping systems were adopted. The $\mathrm{E}$ values ranged from $5.39 \mathrm{~mol} \mathrm{H}_{2} \mathrm{O} \mathrm{m}^{2} \mathrm{~s}^{-1}$ in forages grown under full sunlight to 1.89 and $3.16 \mathrm{~mol} \mathrm{H}_{2} \mathrm{O} \mathrm{m}^{2} \mathrm{~s}^{-1}$, in the intercropping system with forages sown $2.0 \mathrm{~m}$ from the Eucalyptus rows, in $12.0 \times 2.0 \mathrm{~m}$ and $12.0 \times 4.0$-m spacings, respectively. Furthermore, it is noteworthy that forages grown 4.0 and $2.0 \mathrm{~m}$ from Eucalyptus rows had higher E values in the $12.0 \times 4.0-\mathrm{m}$ spacing (Table 3 ).

This finding showed that stomatal water loss results from the sum of plant and environmental factors. Transpiration rate of plants under highdensity treatments and located near the Eucalyptus trees was lower, even with similar Gs values to those of treatments in intercropping systems. This may reflect the decreased vapor pressure gradient between 
the leaf mesophyll spaces and the environment. The different humidity and temperature conditions in those environments decrease the force driving water loss from the leaf to the atmosphere.

Water use efficiency (WUE) of bread grass plants was adversely affected by the understory shading of CLFI systems, with no significant differences observed between forage and tree plants. The WUE decreased by approximately $40 \%$ in bread grass plants grown in rows located $2.0 \mathrm{~m}$ apart from Eucalyptus rows, in the $12.0 \times 2.0 \mathrm{~m}$ spacing. Conversely, the decrease in the $12.0 \times 4.0 \mathrm{~m}$ spacing was approximately $30 \%$ of that in plants sown under full sunlight. No difference in WUE was observed between Eucalyptus at the distances tested (Table 3).

The low transpiration rates observed in the intercropping systems failed to increase the forage water use efficiency, which is slightly contradictory. However, plants must maintain the same quantity of fixed $\mathrm{CO}_{2}$ to obtain higher WUE values. Although a decrease in $\mathrm{Ci}$ was observed under high-density treatments and at $2.0 \mathrm{~m}$ from the Eucalyptus trees, regardless of the forage sowing site (row or inter-row), that decrease in mesophyll $\mathrm{CO}_{2}$ concentration is apparently not associated with the decreased $\mathrm{CO}_{2}$ fixation affecting WUE values. The lowest value of Cireported among all treatments was $77.52 \mu \mathrm{mol} \mathrm{mol}{ }^{-1}$. However, that value is much higher than the minimum necessary for $\mathrm{C} 4$ plants to reach their $\mathrm{CO}_{2}$ compensation point (5 to $10 \mu \mathrm{mol} \mathrm{mol}{ }^{-1}$; TAIZ \& ZEIGER, 2010). Thus, those results clearly showde that other photosynthesis-related factors, including decreased light intensity in intercropped treatments, may be the main factors responsible for decreased $\mathrm{CO}_{2}$ fixation in dry matter, thereby reducing the forage water use efficiency.

The negative change in physiological parameters may be positive when considering the competition between maize and eucalyptus, because competitive capacity of forage for growth resources is reduced. However, changes in forage physiological patterns compromising its full growth and development may compromise pasture formation.

\section{CONCLUSION}

Bread grass cropping in maize inter-rows associated with intense shading provided by decreased Eucalyptus spacing $(12.0 \times 2.0 \mathrm{~m})$ and bread grass proximity to Eucalyptus tree crowns adversely affects the physiological parameters of bread grass. Water use efficiency of bread grass decreases, regardless of the Eucalyptus plot design and distance between forages and trees when the forages are grown in maize rows.

\section{REFERENCES}

BRODRIBB, T. J.; HILL, R. S. Increases in water potential gradient reduce xylem conductivity in whole plants. Evidence from a lowpressure conductivity method. Plant Physiology, v.123, n.3, p.10211027, 2000. Available from: <http://www.ncbi.nlm.nih.gov/pmc/ articles/PMC59065/pdf/pp001021.pdf>. Accessed: Jul. 20, 2015. doi: 10.1104/pp.123.3.1021.

COCHARD, H. et al. Unraveling the effects of plant hydraulics on stomatal closure during water stress in walnut. Plant Physiology, v. 128, n. 1, p. 282290, 2002. Available from: $<$ http://www.plantphysiol.org/content/128/1/282. short>. Accessed: Dec. 20, 2015 doi: 10.1104/pp.010400.

CONCENCO, G. et al. Water use in Italian Ryegrass (Lolium multiflorum) biotypes under competition. Planta Daninha, v.25, n.3, p.449-455, 2007. Available from: <http://www.scielo.br/scielo. php?pid $=S 010083582007000300003 \&$ script $=$ sci_arttext\&tlng $=$ pt $>$. Accessed: Oct. 18, 2015. doi:10.1590/s0100-83582007000300003.

KUBÁSEK, J. et al. C4 plants use fluctuating light less efficiently than do C3 plants: a study of growth, photosynthesis and carbon isotope discrimination. Physiologia plantarum, v.149, n.4, p.528-539, 2013. Available from: <http://onlinelibrary.wiley.com/doi/10.1111/ppl.12057/ full>. Accessed: Dec. 20, 2015. doi: 10.1111/ppl.12057/full.

LORETO, F.; BONGI, G. Combined low-temperature high light effects on gas-exchange properties of jojoba leaves. Plant Physiology, v.91, n.4, p.1580-1585, 1989. Available from: <http://www. plantphysiol.org/content/91/4/1580.short>. Accessed: Dec. 20, 2015. doi: 10.1104/pp.91.4.1580.

MADDONNI, G. et al. Plant population density, row spacing and hybrid effects on maize canopy architecture and light attenuation. Field Crops Research, v.71, n.3, p.183-193, 2001. Available from: <http:// www.sciencedirect.com/science/article/pii/S0378429001001587>. Accessed: set. 02, 2015. doi:10.1016/S0378-4290(01)00158-7.

OCHELTREE, T. et al. Stomatal responses to changes in vapor pressure deficit reflect tissue-specific differences in hydraulic conductance. Plant, Cell \& Environment, v.37, n.1, p.132-139, 2014. Available from: <http:// onlinelibrary.wiley.com/doi/10.1111/pce.12137/full> Accessed: Dec. 04, 2015. doi: $10.1111 /$ pce.12137/full.

PACIULLO, S.C.D. et al. Morphophysiology and nutritive value of signalgrass under natural shading and full sunlight. Pesquisa Agropecuaria Brasileira, v.42, n.4, p.573-579, 2007. Available from: <http://www.scielo.br/scielo.php?pid=S0100204X2007000400016\&script=sci arttext\&tlng=es $>$. Accessed: Jun. 28, 2015. doi: 10.1590/s0100-204x2007000400016.

RITCHIE, S.W. et al. Howacorn plant develops? Ames: Iowa State University of Science and Technology, 1993. 26p. (Special Report, 48).

SHARKEY, T.D.; RASCHKE, K. Effect of light quality on stomatal opening in leaves of xanthium-strumarium L. Plant Physiology, v.68, n.5, p.11701174, 1981. Available from: <http://www.plantphysiol.org/content/68/5/1170. short $>$. Accessed: Feb. 15, 2015. doi: 10.1104/pp.68.5.1170.

TAIZ, L.; ZEIGER, E. Plant physiology 5th Ed. Sunderland, MA: Sinauer Associates, 2010.

WELLES, J.M.; NORMAN, J.M. Instrument for indirect measurement of canopy architecture. Agronomy Journal, v.83, n.5, p.818-825, 1991. Available from: <https://dl.sciencesocieties.org/publications/aj/ abstracts/83/5/AJ0830050818>. Accessed: Feb. 20, 2015. 